\title{
Pengembangan Media Bimbingan Kelompok dengan Video dalam Meningkatkan Pemahaman Mengenai Pelecehan Seksual untuk Siswa Sekolah Menengah
}

\author{
Nadya Yaniar Nafis*, Yuliati Hotifah, Adi Atmoko \\ Universitas Negeri Malang, Jl. Semarang No. 5 Malang, Jawa Timur, Indonesia \\ *Penulis korespondensi, Surel: nadyayaniar@gmail.com
}

Paper received: 25-8-2021; revised: 8-9-2021; accepted: 15-9-2021

\begin{abstract}
This study aims to develop a media of group guidance service with video to increase the understanding about sexual harassment for junior high school students. In this research and development, researchers develop the products as videos and guidebooks. This study uses the type of research and development that uses the Research and Development model by Borg and Gall. There are steps in this research and development are research and data collection, planning, development of initial product drafts, expert trials, product revisions, field trials and final product revisions. The developed products need to be tested by material experts, media and potential users. In analyzing the results of the expert test and the prospective user test, the researcher used a range of data analysis. The results of the analysis of the material expert test in the form of a feasibility presentation of 3.7 and the results of the analysis of the media expert test in the form of a feasibility presentation of 3.93. Based on the results of the analysis, all of them show that the product developed is very feasible so that it can be used by school counselors.
\end{abstract}

Keywords: video media; media of group guidance; sexual harassment

\begin{abstract}
Abstrak
Penelitian ini bertujuan mengembangkan media layanan bimbingan kelompok dengan video dalam meningkatkan pemahaman mengenai pelecehan seksual untuk siswa sekolah menengah pertama. Pada penelitian dan pengembangan ini, peneliti mengembangkan produk berupa video beserta buku panduannya. Penelitian ini menggunakan jenis penelitian dan pengembangan yang menggunakan model Research and Development oleh Borg and Gall. Adapun langkah dalam penelitian dan pengembangan ini yaitu penelitian dan pengumpulan data, perencanaan, pengembangan draf produk awal, uji coba ahli, revisi produk, uji coba lapangan dan revisi produk akhir. Produk yang dikembangkan perlu dilakukan uji ahli materi, media dan calon pengguna. Dalam menganalisis hasil uji ahli dan uji calon pengguna, peneliti menggunakan analisis data rentangan. Adapun hasil analisis uji ahli materi berupa presentasi kelayakan sebesar 3,7 dan hasil analisis uji ahli media berupa presentasi kelayakan sebesar 3,93. Berdasarkan hasil analisis dari seluruhnya menunjukan bahwa produk yang dikembangkan sangat layak sehingga dapat digunakan konselor sekolah.
\end{abstract}

Kata kunci: media video; media bimbingan kelompok; pelecehan seksual

\section{Pendahuluan}

Negara Indonesia yang terkenal akan keramahan warganya kini darurat kekerasan seksual. Kasus tindak kekerasan seksual yang dulu jarang terdengar, kini semakin marak disiarkan pada berbagai media massa. Hal ini didukung dengan data jumlah Kekerasan Terhadap Perempuan (KTP) pada tahun 2019 yakni sebesar 431.471, jumlah ini meningkat dibandingkan dengan tahun sebelumnya (2018) sebesar 406.178 (Komnas Perempuan, 2020). Begitu pula dengan salah satu kota di Indonesia yang terkenal dengan julukan Kota Pendidikan yaitu Kota Malang. Dibalik indahnya julukan tersebut, terdapat kejadian miris pada awal bulan Februari 2019, yaitu tindak pelecehan seksual yang dilakukan oleh seorang oknum guru 
Sekolah Dasar dimana korbannya merupakan 20 siswa Sekolah Dasar (Surya.co.id, 2019). Pada Tahun 2019, tercatat 50 kasus kekerasan pada anak tercatat dan ditangani Dinas Pemberdayaan Perempuan, Perlindungan Anak, Pengendalian Penduduk dan Keluarga Berencana (DP3AP2KB) Kota Malang (Malangpost.com, 22/01/2020).

Pengalaman di lapangan pada kasus pelecehan seksual yang peneliti temui yaitu ketika melaksanakan Pengenalan Lapangan Persekolahan (PLP) di Sekolah Menengah Pertama Negeri 4 Malang. Seorang siswa berinisial 'D' kelas VII Sekolah Menengah Pertama Negeri 4 Malang diketahui telah melakukan tindak pelecehan seksual pada teman kelasnya sebanyak 2 kali. Hal ini diketahui ketika korban berani melapor. Selain kasus tersebut, terdapat kasus lain mengenai pelecehan seksual yang dilakukan siswa lain. Konselor sekolah menyatakan pada tahun lalu terdapat kejadian serupa, yaitu siswa yang menyentuh pantat siswi dengan alasan bercanda. Konselor sekolah juga menuturkan bahwa tindak pelecehan seksual lebih sering menimpa siswi kelas tujuh. Berdasarkan hal tersebut dapat disimpulkan bahwa tindak pelecehan seksual dapat terjadi dimanapun termasuk di sekolah.

Adapun penelitian terdahulu yaitu layanan preventif dalam pencegahan tindak pelecehan seksual. Seperti penelitian oleh Firman dan Syahniar (2018) yakni Pencegahan Pelecehan Seksual Remaja Melalui Layanan Informasi Menggunakan Pendekatan Contextual Teaching And Learning Di Sekolah Menengah Atas (SMA). Pada penelitian ini menggunakan metode kuantitatif. Hasil penelitian menunjukkan bahwa layanan informasi menggunakan Contextual Teaching and Learning efektif untuk pencegahan pelecehan seksual remaja SMA. Hasil penelitian terdahulu dapat membantu siswa dalam mencegah tindak pelecehan seksual, namun pada penelitian tersebut tertuju pada siswa SMA saja tidak dapat diterapkan pada jenjang pendidikan lainnya mengingat karakteristik siswa tiap jenjang pendidikan berbeda.

Berdasarkan penjelasan diatas, penulisan ini bertujuan agar siswa memahami dan mengetahui apa itu tindakan pelecehan seksual sehingga dapat mencegah tindak pelecehan seksual terjadi. Hal tersebut dapat diwujudkan dengan memberikan pengetahuan mengenai pelecehan seksual melalui pengembangan media layanan bimbingan kelompok dengan video dalam meningkatkan pemahaman mengenai pelecehan seksual untuk siswa sekolah menengah pertama.

\section{Metode}

Penelitian ini menggunakan metode penelitian dan pengembangan. Menurut Sugiyono (2015), penelitian dan pengembangan atau dalam bahasa inggris research and development adalah metode penelitian yang digunakan untuk menghasilkan produk tertentu, dan menguji keefektifan produk tersebut. Alasan pemilihan model penelitian dan pengembangan adalah karena penelitian ini nantinya akan menghasilkan produk yang dapat digunakan konselor sekolah dalam memberikan layanan pada siswa. Selain itu, model ini relatif fleksibel dimana peneliti dapat memilih tahap mana yang sesuai dengan kebutuhan dan tahap yang kurang sesuai dapat ditinggalkan. Hal ini dirasa cocok untuk mengembangkan media bimbingan kelompok dengan video dalam meningkatkan pemahaman mengenai pelecehan seksual untuk siswa sekolah menengah pertama. Subjek dalam penelitian dan pengembangan ini adalah siswa kelas 7.

Prosedur dalam penelitian dan pengembangan ini merupakan adaptasi dari prosedur pengembangan Borg \& Gall (1989). Pada penelitian ini peneliti hanya menggunakan 7 prosedur pengembangan dari 10 prosedur. Penggunaan 7 tahap dalam penelitian ini dirasa 
cukup karena sasaran pengguna media ini adalah konselor sekolah yang dalam tahapan ini menjadi uji ahli. Adapun langkah-langkah prosedurnya yaitu penelitian dan pengumpulan data, perencanaan, pengembangan draf produk awal, uji coba ahli, revisi produk, uji coba lapangan dan revisi produk akhir.

Terdapat dua tahapan dalam melakukan desain uji coba. Yang pertama yaitu uji ahli yang dilakukan untuk mengetahui keberterimaan produk penelitian dan memberikan penilaian pada setiap aspek ketepatan, kegunaan, kemenarikan dan kemudahan. Tahap kedua yaitu uji calon pengguna produk yang dilakukan oleh konselor sekolah dengan tujuan untuk mengetahui keberterimaan produk yang telah dibuat dari segi ketepatan, kegunaan, kemenarikan, dan kemudahan media yang akan diberikan pada siswa.

Instrumen pengumpulan data awal adalah instrumen yang digunakan sebelum produk dibuat. Instrumen berupa inventori pemahaman pelecehan seksual untuk mengetahui need asessment siswa. Sedangkan instrumen uji ahli dan uji calon pengguna berupa format penilaian.

Data yang diperoleh dalam penelitian ini berbentuk data kuantitatif dan data deskriptif. Data deskriptif yang dihasilkan berupa kritik, saran dan tanggapan dari uji ahli. Tahapan dalam penganalisisan data deskriptif atau kualitatif antara lain reduksi data, display data, kesimpulan dan verifikasi (Miles, dkk, 2013). Sedangkan untuk data kuantitatif menggunakan analisis data rentangan.

\section{Hasil dan Pembahasan}

\subsection{Hasil}

Produk yang dikembangkan dalam penelitian ini berupa media video beserta buku panduan. Media video yang dikembangkan berbentuk perpaduan yang menampilkan ekspositori narator dan animasi dengan tema pemahaman tentang pelecehan seksual. Media video terdiri dari 3 bagian yaitu pembuka, isi dan penutup. Dalam bagian isi terdiri dari 4 bab diantaranya yaitu, pengertian pelecehan seksual, macam-macam pelecehan seksual, faktor penyebab terjadinya pelecehan seksual dan dampak pelecehan seksual. Video tersebut berduarasi 6 menit. Agar konselor dapat memberikan layanan bimbingan kelompok dengan media video yang telah dikembangkan peneliti, diperlukan buku panduan guna mempermudah konselor. Buku panduan penggunaan media video terdiri dari beberapa bagian yaitu pengantar, pendahuluan, kajian teori, petunjuk penggunaan, penutup, serta profil Pengembang dan profil lembaga. Buku panduan ini berukuran A5 dengan jenis huruf Adobe Garamond Pro Bold dengan ukuran 12 .

Produk yang dikembangkan telah tervalidasi oleh ahli materi bimbingan dan konseling, ahli media oleh dosen teknologi pendidikan serta calon pengguna produk yaitu konselor sekolah. Penilaian produk yang diberikan terdiri dari data kuantitatif dan data kualitatif. Data kuantitatif merupakan data yang diperoleh dari hasil penilaian yang diberikan didasarkan pada 4 aspek keberterimaan yaitu ketepatan, kegunaan, kemudahan, dan kemenarikan. Sedangkan data kualitatif diperoleh dari hasil kritik dan saran yang diberikan oleh penguji.

Hasil penilaian uji ahli materi menunjukkan nilai presentasi kelayakan sebesar 3,7 yang termasuk dalam kategori sangat layak. Hasil penilaian ahli media memberikan penilaian 
berupa presentasi kelayakan sebesar 3,93 yang termasuk dalam kategori sangat layak. hasil penilaian calon pengguna memberikan penilaian berupa presentasi kelayakan sebesar 3,75. Jika disimpulkan, rata-rata hasil penilaian uji ahli, uji media dan calon pengguna termasuk dalam kategori sangat layak.

\subsection{Pembahasan}

Penelitian dan pengembangan ini menghasilkan sebuah produk yaitu media video beserta buku manual dalam meningkatkan pemahaman tentang pelecehan seksual untuk siswa sekolah menengah pertama. Media video merupakan media yang dapat digunakan konselor dalam memberikan layanan bimbingan kelompok dalam meningkatkan pemahaman tentang pelecehan seksual, sedangkan buku panduan merupakan sebuah petunjuk bagi konselor untuk penggunaan media video. Produk ini dibuat berdasarkan need assessment yang telah dilaksanakan oleh peneliti di SMP Negeri 4 Malang.

Media video yang dikembangkan berbentuk perpaduan yang menampilkan ekspositori narator dan animasi dengan tema pemahaman tentang pelecehan seksual. Media video terdiri dari 3 bagian yaitu pembuka, isi dan penutup. Pada bagian pembuka terdapat pemaparan kasus mengenai pelecehan seksual. Pada bagian isi terdiri dari 4 bab diantaranya yaitu, pengertian pelecehan seksual, macam-macam pelecehan seksual, faktor penyebab terjadinya pelecehan seksual dan dampak pelecehan seksual. Sedangkan pada bagian penutup terdapat ucapan terimakasih dan anjuran mematuhi protokol kesehatan. Video tersebut berdurasi 6 menit.

Agar konselor dapat memberikan layanan bimbingan kelompok dengan media video yang telah dikembangkan peneliti, diperlukan buku panduan guna mempermudah konselor. Buku panduan penggunaan media video terdiri dari beberapa bagian yaitu pengantar, pendahuluan, kajian teori, petunjuk penggunaan, penutup, serta profil pengembang dan profil lembaga. Buku panduan ini berukuran A5 dengan jenis huruf Adobe Garamond Pro Bold dengan ukuran 12.

Analisis keseluruhan terhadap hasil penilaian ahli materi memberikan penilaian berupa presentasi kelayakan sebesar 3,7 yang termasuk dalam kategori sangat layak. Hasil penilaian ahli materi secara keseluruhan dapat dimaknai bahwa produk media bimbingan kelompok dengan video dalam meningkatkan pemahaman mengenai pelecehan seksual untuk siswa sekolah menengah pertama merupakan media pembelajaran yang sangat berterima, tepat dan jelas untuk digunakan oleh konselor sekolah.

Analisis keseluruhan terhadap hasil penilaian ahli media memberikan penilaian berupa presentasi kelayakan sebesar 3,93 yang termasuk dalam kategori sangat layak. Hasil penilaian ahli media secara keseluruhan dapat dimaknai bahwa produk media bimbingan kelompok dengan video dalam meningkatkan pemahaman mengenai pelecehan seksual untuk siswa sekolah menengah pertama merupakan media pembelajaran yang sangat berterima, tepat dan jelas untuk digunakan oleh konselor sekolah

Analisis keseluruhan terhadap hasil penilaian calon pengguna memberikan penilaian berupa presentasi kelayakan sebesar 3,75 yang termasuk dalam kategori sangat layak. Hasil penilaian ahli media secara keseluruhan dapat dimaknai bahwa produk media bimbingan kelompok dengan video dalam meningkatkan pemahaman mengenai pelecehan seksual untuk 
siswa sekolah menengah pertama merupakan media pembelajaran yang sangat berterima, tepat dan jelas untuk digunakan oleh konselor sekolah.

Penelitian terdahulu oleh Firman dan Syahniar (2018) yakni Pencegahan Pelecehan Seksual Remaja Melalui Layanan Informasi Menggunakan Pendekatan Contextual Teaching And Learning Di Sekolah Menengah Atas (SMA). Hasil penelitian menunjukkan bahwa layanan informasi menggunakan Contextual Teaching and Learning efektif untuk pencegahan pelecehan seksual remaja SMA. Pada penelitian ini menggunakan metode kuantitatif. Hasil penelitian menunjukkan bahwa layanan informasi menggunakan Contextual Teaching and Learning efektif untuk pencegahan pelecehan seksual remaja SMA. Hasil penelitian terdahulu dapat membantu siswa dalam mencegah tindak pelecehan seksual, namun adapun kelemahan pada penelitian tersebut yaitu penelitian tersebut tertuju pada siswa SMA sehingga tidak dapat diterapkan pada jenjang pendidikan lainnya mengingat karakteristik siswa tiap jenjang pendidikan berbeda.

Berdasarkan hal tersebut, peneliti mengambangkan media layanan bimbingan kelompok dengan video dalam meningkatkan pemahaman mengenai pelecehan seksual untuk siswa sekolah menengah pertama. Tujuan penelitian ini adalah sebagai langkah preventif agar siswa dapat mencegah dari tindak pelecehan seksual karena telah memahami dan mengetahui apa itu tindakan pelecehan seksual hingga dampak dan faktor penyebabnya.

\section{Simpulan}

Berdasarkan hasil analisis dapat ditarik kesimpulan sebagai berikut: (1) Produk media video beserta buku panduannya yang telah dikembangkan memenuhi unsur keberterimaan media yakni ketepatan, kegunaan, kemenarikan, kemudahan dan isi keseluruhan panduan. Keberterimaan pada ini menunjukkan bahwa panduan tersebut telah berterima dan dapat digunakan sebagai media pembelajaran bagi konselor di sekolah. (2) Produk yang telah dikembangkan memenuhi unsur keberterimaan isi materi bimbingan kelompok yang berfokus pada peningkatan pemahaman tentang pelecehan seksual siswa SMP dengan kategori sangat tinggi. Keberterimaan isi media dan buku panduannya ini menunjukkan bahwa panduan tersebut telah berterima sebagai layanan bimbingan kelompok oleh konselor di sekolah.

Beberapa hal tersebut disampaikan saran-saran sebagai berikut. (1) Sebelum menggunakan produk yang telah dikembangkan peneliti, konselor sekolah dapat mempelajari dan memahami petunjuk penggunaan produk yang telah tersedia dalam buku panduan penggunaan produk. Hal ini berguna agar proses pemberian layanan dapat berjalan secara efektif dan evisien. (2) Saran pengembangan lebih lanjut yaitu. Pertama, Pengembangan panduan ini belum dilakukan uji keefektifan dikarenakan penelitian dan pengembangan ini hanya sampai pada tahap ke-7 Borg \& Gall (1983), sehingga bagi peneliti selanjutnya dapat dilakukan pengujian keefektifan produk terhadap siswa-siswa Sekolah Menengah Pertama 4 Malang atau siswa-siswa di sekolah lain yang memiliki kasus pelecehan seksual. Kedua, Penelitian pengembangan panduan ini mengadaptasi model penelitian pengembangan Borg \& Gall (1983), namun dalam penelitian dan pengembangan ini peneliti hanya melewati langkah pertama hingga ketujuh. Maka saran untuk peneliti selanjutnya adalah melanjutkan sampai pada tahap ke-10 metode penelitian dan pengembangan.

\section{Daftar Rujukan}

Borg, W.R. \& Gall, M. D. (1989). Educational Research: An Introduction (5th ed). New York : Longman 
Firman \& Syahiar. (2018). Pencegahan Pelecehan Seksual Remaja Melalui Layanan Informasi Menggunakan Pendekatan Contextual Teaching And Learning di Sekolah Menengah Atas (SMA). Jurusan Bimbingan dan Konseling Universitas Negeri Padang

Komnas Perempuan. (2020). Catatan Tahunana Tentang Kekerasan Terhadap Perempuan Tahun 2019. Dari website kompas perempuan : https://komnasperempuan.go.id/

Malangpost.com. (2019). Kekerasan Anak Ada di Sekitar Kita. Dari website Malang Post : https://malangpost.com/berita/detail/kekerasan-anak-ada-di-sekitar-kita/

Miles, M. B., Huberman, A. M., \& Saldana, J. (2014). Qualitative Data : Analysisis A Methods Sourcebook (3rd ed). USA : SAGE Publications

Sugiyono. (2015). Metode Penelitian Kuantitatif, Kualitatif, dan R\&D. Bandung : Alfabeta

Surya.co.id. (2019). Siswi SD Korban Pelecehan Seksual Oknum Guru di Kota Malang Diduga Lebih dari 20 Anak. Dari Website Surya : https://surabaya.tribunnews.com/2019/02/11/siswi-sd-korbanpelecehan-seksual-oknum-guru-di-kota-malang-diduga-lebih-dari-20-anak?page=all/ 